\title{
How to watch television? Pedagogy and paedocracy in Beckett's television plays
}

Article

Accepted Version

Bignell, J. (2005) How to watch television? Pedagogy and paedocracy in Beckett's television plays. Samuel Beckett Today / Aujourd'hui, 15. pp. 281-293. ISSN 0927-3131 (Historicising Beckett / Issues of Performance) Available at https://centaur.reading.ac.uk/40510/

It is advisable to refer to the publisher's version if you intend to cite from the work. See Guidance on citing.

Published version at: http://www.ingentaconnect.com/content/rodopi/sbta/2005/00000015/00000001/art00025

Publisher: Rodopi

All outputs in CentAUR are protected by Intellectual Property Rights law, including copyright law. Copyright and IPR is retained by the creators or other copyright holders. Terms and conditions for use of this material are defined in the End User Agreement.

\section{www.reading.ac.uk/centaur}

\section{CentAUR}

Central Archive at the University of Reading

Reading's research outputs online 
HOW TO WATCH TELEVISION?:

Pedagogy and Paedocracy in Beckett's Television Plays

\author{
Jonathan Bignell
}

This article responds to scholarship on Beckett's television plays that regards them as positive interventions which encourage the viewer to reconsider the conventions of the medium, and that raise the cultural standards of television drama. In making claims about how the plays address and educate their viewers, critical approaches shift between conceptions of audience. This analysis of Beckett's plays on British television reconsiders their aesthetic strategies, their relationship with television culture, and the dominant assumptions of critical writing about them by examining the parallel between conceptions of the audience and conceptions of the child in writing about television and Beckett's television plays.

By considering the critical claim that Beckett's television plays teach their audiences how to watch television, in the light of different models of audience address and reception held by academic critics and the television industry, this article argues that Beckett's television work opens up significant cultural issues around the functions of television in culture, television aesthetics, and conceptions of the television audience. The status of the audience in debates about the role of television in society is that of an 'other', variously to be taught, given pleasure, placated or improved by television. This is parallel and analogous to discourses that pose the identity of the child as other. The article argues that the problem of the function of television in society can be cast in terms of the contested and contradictory notions of the child. Posed as both innocent and fallen, rational and irrational, powerless and powerful, the child and the television audience are impossible referents for critical discourse. Each of them represents the other to which prescriptive discourses refer, and on whose behalf they make aesthetic and political judgements. Critical writing on Beckett's television plays has adopted these prescriptive discourses and thus engaged problematically with assumptions about the television medium and the place of Beckett's work in relation to it. 


\section{Beckett, Television Audiences and the Notion of the Child}

Beckett critics have argued that his television work is important because it is radically different from the television culture that surrounds it, and has a productive role in turning the audience from passive viewers into active and reflective ones. Linda Ben-Zvi, for example, argued that Ghost Trio (1977) used V's voice-over address to the viewer in a way that makes the play become about the act of seeing. V in Part 1 trains the viewer's attention on sections of the room, signalling the recurrent rectangles, the dominant form in Ghost Trio. Each rectangular shape is seen against a still larger rectangle [...]. All these rectangles, of course, are subsumed in the framing rectangle of the television screen, possibly being viewed in the rectangle of "the familiar room" of the viewer: world within world ever expanding - or receding. Once she has taught the viewer how to see, $\mathrm{V}$ teaches the viewer how to perceive movement around these rectangular shapes.

(Ben-Zvi 1985, 34-5)

Similarly, in ...but the clouds.. (1977) and Quad (1982), the frame of the screen is accentuated by the framing of the characters by lighting, producing an unlit off-screen space which is neither identifiable with the studio set or a fictive location. This continues the emphasis on framing produced in Ghost Trio by the rectangles of the floor, wall, and F's pallet which each mirror the square television screen. The audio-visual forms in Beckett's television plays have legitimated approaches that emphasise their reflexivity and their critical work on the television audience.

The group most often thought to need this kind of awareness of medium is the child audience. Concern about children's television viewing legitimates parents' control over it, legal regulation and censorship. These interventions rest on stated or unstated theories of childhood and media culture, but although the figure of the child is massively present in discourses about television, it is only there as the referent of others' discourses. The child is constructed by these discourses either as a vulnerable being to be protected from media influence, or as an adult-inprocess with opinions, fears and desires of his or her own and an entitlement to media experiences. These contradictory conceptions co-exist, and show that thinking about children's interactions with television is simply a special case of the larger question of the relationship between audiences and television. Concerns around the child audience instantiate broader questions about what television is for, who it is for, and how it is watched (Bignell 2002). Notions of the child and of the audience position each of them as enigmatic and suggestible others. When child audiences are regarded as a suggestible and homogenous, they are simply occupying the place of the television audience in general inasmuch as the audience is seen as a mass whose passivity and lack of sophistication is explained as an effect of television, and/or an alibi for intervention into it. This othering of the audience has structured debates around Beckett's television work. 


\section{The Pedagogical Address to the Audience}

The media theorist John Hartley (1992) introduced the terms pedagogy and paedocracy in order to describe a struggle for control over television audiences. Hartley's argument adopts the child as a figure for the othering process through which television institutions and the institutions which represent it both disempower the audience and, simultaneously, value it because programmes are made for and in the name of audiences. He argued that the audience, like the child, is regarded as both valuable and unruly, both under television institutions' pseudo-parental control but also able to evade this control. So institutions develop strategies to address an audience on which they depend, but which they also patronise and demean. The paedocratic relation to the audience is based on satisfying its presumed desire to regress to a childlike state characterised by a search for pleasure, entertainment and distraction. In contrast, the pedagogic mode attempts to educate and mature the audience. Pedagogic strategies include the promotion and reviewing of television, which instruct the audience about programmes and how to watch them, as well as censorship and regulation by government or educational institutions. The adoption of textual strategies such as the explicit address to the audience by V in Ghost Trio, 'Keep that sound down', and the lengthy shots showing the rectangular shapes of the set, are pedagogic inasmuch as they explicitly prescribe ways of viewing and comprehension, and discipline their audience.

The pedagogic requirement to give attention and concentration to Beckett's plays for television and the BBC arts programmes under whose auspices they were screened is at odds with conventional paedocratic discourses that posit an inattentive, grazing viewer. Adaptations of Beckett's theatre plays were almost all presented by Arena, BBC2's flagship arts programme, while The Lively Arts, another BBC2 arts programme, first broadcast Ghost Trio and ...but the clouds... in 1977 under the title Shades. This is highly significant to their address to the audience. Television programmes are the majority of television viewers' primary access to the arts (Walker 1993). Thus television has a exhibition and curatorial function that associates it with pedagogy in general and sometimes with educational broadcasting explicitly. Television can simply relay preexisting work (by broadcasting a theatrical performance of a Beckett play, for example) or become a medium of artistic exploration in itself. The role of presenters and explanatory or contextual material, and the scheduling of arts programmes, take into account the presumed purpose of programmes and their expected audiences. Television is regarded as the most accessible broadcasting medium, yet despite this, and also because of it, television is at the margins of cultural authority and has moved increasingly towards paedocratic policies, becoming increasingly shy of pedagogic audience address.

The cost of Shades was largely covered by a co-production agreement with the Munichbased company Reiner Moritz, which regularly collaborated with the BBC on arts programmes (like Robert Hughes's The Shock of the New, 1980) rather than drama. This production context, and the plays' scheduling within an arts strand, position them within debates about arts 
programming and its relation to its subject and audience. However, Beckett's dramas themselves were more similar to television studio drama productions than video art for television or factual programmes about the arts, since they adopted conventions of dramatic staging, performance and narrative. Beckett's work was drama that was offered to the audience as a special arts event. Its formal experimentation and demands on the viewer tended to marginalize it outside of the production and reception contexts of television plays, which were increasingly grouped under collective titles such as BBC's Play for Today (1974-80), and producers focused on continuing series which offered lower production costs and greater continuity of audience from week to week (Bignell 2001-2). As the broadcasting of drama moved towards the paedocratic, satisfying perceived audience expectations, Beckett's plays harked back to a pedagogic form that became increasingly rare.

The plays' apparently pedagogic and uncompromising address to the viewer is exactly what academic writing has valued about them. Linda Ben-Zvi (24) has argued that Beckett's plays for television and radio educate the audience about their means of production: "Beckett foregrounds the devices - radio sound effects, film and video camera positions - and forces the audience to acknowledge the presence of these usually hidden shapers of texts". Thus the plays are argued to empower the audience by requiring attention to the conventions of signification in the medium. This matches educationalists' arguments for children to study the media at school, learning 'media literacy' which comprises knowledge of genre, narrative codes and production processes (Hodge and Tripp 1986). Critical discourse on Beckett's television plays values their pedagogic strategies for teaching media literary to adults, paralleling the adult audience with children, and paralleling Beckett's plays with children's programming. This seems distant from television's usual paedocratic promise of viewing pleasure, but might offer a 'higher' pedagogic pleasure in which perceptual capacities are refined. Indeed, the research by David Buckingham (1996) on children's responses to television argues that watching television enables children to understand themselves and to gain and deploy media literacy. From this perspective, it is not simply pleasure that drives viewing preferences (paedocratic impulses), but also a desire to self-educate and confront challenging material (a pedagogic viewing position). Critics have valued Beckett's plays as ways for viewers to understand and explore problems of identity, death, love, and meaning in general, as a counter-strategy to some of these critics' assumptions about television's role in cultural dumbingdown. Jonathan Kalb $(1994,137)$, for example, claims that "television has been dominated by the narrowly circumscribed formats of commercial programming since its birth, and those formats have contributed to egregious, worldwide psychological changes: shrinking attention spans, discouraging reading and encouraging passive, narcotized habits of viewing art of all kinds". These are exactly the effects that television has been claimed to have on children. Kalb argues that Beckett can "augment human perception and, by implication, dignify it" (138), thus leading adults away from television's pernicious influence. 
If Beckett's television plays teach the audience how to watch television, they can be compared to the programmes with pedagogic aims made for child audiences. The BBC producer Roger Singleton-Turner, for example, argued that programmes for children should have greater regard for the functions of television in education and child development. His book Television and Children (1994) is both a guide for programme-makers and also addresses educators, parents and politicians. Singleton-Turner draws on developmental psychology and the professional discourse of television production when he asserts: "The whole grammar of television needs to be learnt by each viewer. There is evidence that the language of film and television is learnt in a similar way to spoken language and that children of increasing maturity accept with understanding an increasing vocabulary of filmic conventions" (23). Therefore, narrative forms should be relatively linear and clear, relations between long shots and close ups should be signposted (to avoid confusion over the sizes of objects and people), time ellipses between shots should be rare, and cutting rates should be slow. The discourse frames child development as an evolutionary learning process moving teleologically towards normative adult viewership. The form of children's programmes comes to resemble early cinema, repeating the 'evolution' of film from a static camera shooting theatrical box sets, with little cutting or change of frame size, to a contemporary style of rapid montage, fast cutting, and 'unmotivated' use of pan or close up in programmes for older children. If Beckett's plays seem to be going back to the beginnings of audio-visual "grammar", they match the prescriptions made by Singleton-Turner for programmes aimed at children of kindergarten age., and the instructional functions of such programmes.

There are striking similarities between the professional codes in programme-making for children and the structural principles and audience address of Beckett's television plays. In each, there are simple relations between shots, long takes, clear establishing shots that introduce a performance space, guiding narration, and use of compositional and editing conventions deriving from early cinema and television. Eh Joe (1966) and Ghost Trio both begin with static establishing shots that present the whole of the acting area, and only then proceed to segment that space by cutting and camera movement, while Quad uses only one camera position that has a similarly complete view of the space where action takes place. Eckart Voigts-Virchow $(1998,235)$ asks "How does this formal examination of Beckett's camera plays, then, position their reductive, repetitive, static, monochrome, interior closeness in the TV environment?", and answers that it sidelines them as outdated and rarefied (both rarely-seen and aimed at an elite audience). But the learning curve of child viewers in watching programmes made for them is parallel to the notion of 'learning to see' that Beckett's plays use as their mode of address to their viewers. So, like programmes for children, Beckett's television plays become a condensed version of the normative and teleological history of audio-visual communication, perhaps producing a reductive view of both media history and audio-visual 'language acquisition'. 
However, Beckett's and other Modernist practitioners' exploration of perception is the ground on which formal experiment and reflexivity of medium are built. By modeling the perceptual processes of the eye by means of the camera, for instance, the fundamentals of perception could be explored (as in the work of Eisenstein or Dziga-Vertov). Furthermore, the recognition of differences between perceptual machines (such as film cameras) and human perceptual organs both de-naturalised human perception and offered possibilities for thinking otherwise. The art historian Ernst Gombrich (1960, 250), for instance, quoted John Ruskin's nineteenth-century invocation of the 'natural' innocence of perception only to refuse it: "The whole technical power of painting depends on our recovery of what might be called the innocence of the eye; that is to say, a sort of childish perception of these flat stains of colour, merely as such, without consciousness of what they signify". For Gombrich, modern art thematises and reflects on perception and representation in a way which debunks the Ruskinian myth of childlike, innocent perception. From this perspective, Beckett's return to the apparent building-blocks of perceptual sense-making can be understood as a critical project to repeat the process of 'learning to see' in order to defer and differentiate it: to suggest precisely the non-necessity of its conventional forms. In this regard, in distinction to the assumptions of Singleton-Turner, the notions of the child's perceptual capacities and of childlikeness function as terrains for critical experiment in television aesthetics and audience address, as long as television allows a space for pedagogy.

\section{Beckett and the Persistence of Television Pedagogy}

The pedagogic relation to the audience has an institutional and cultural authority that reaches back to the foundation of broadcasting in Britain. While Beckett's plays were being produced by the $\mathrm{BBC}$ the power of the pedagogic discourse waned substantially, and has largely been overtaken by a paedocratic relation to the audience. Existing academic work on Beckett's television plays inhabits this dialectical tension between paedocracy and pedagogy, and is a component of a wider debate about the legacy of Modernism and the functions of 'elite' and 'popular' culture. The institution of Beckett criticism derives its notions of the politics of textuality and spectatorship from the Modernist avant-garde in which Beckett was a leading figure, and this is matched by shared interests and cultural aims among television personnel and the arts establishment, in the 1960s especially (Bignell 2003). Writers who the BBC approached in the early 1960s to commission work for television were exploring questions of form and signification. For example, a television version of Beckett's Krapp's Last Tape was screened by BBC in November 1963 in the Festival series of plays, which also included an adaptation of Joyce's Ulysses and plays by Jean Cocteau and T.S. Eliot. As I have argued elsewhere (Bignell 2001-2), Beckett's television plays represent an avant-garde tradition that connects to Modernism in television, film, radio, theatre, literature and 
the visual arts, which explains Beckett's return to apparently outdated aesthetic forms from theatre and early cinema as a strategy for exploring the possibilities of the medium.

In the 1960s, a liberal discourse about the media linked Modernist pedagogical aims to expand audiences' intellectual horizons with a paedocratic discourse that valued childhood and childlikeness as a mode of liberated perception. Marshall McLuhan (1987, first published 1964), for example, argued that television viewers interacted with the medium in parallel ways to children's supposed creative and involved relation to the world. McLuhan proposed that electronic media surpassed the linear, rationalistic and literary heritage of Western civilisation by returning to an iconic, tribal and bardic mode which he associated both with 'primitive' societies and with Modernist art. Like some of the popular movements of the time which drew on Romantic conceptions of childhood, nature, and organic social utopianism, McLuhan called for the reinvigoration of technological culture by a paradoxical return to a preexisting Nature embodied by the child. Both broadly positive and negative theories of media draw on childhood in ways which largely reinforce conventional understandings of the child as different to adults, and socially and culturally in process. The figure of the child was a key component in understanding a Western metropolitan society perceived to be dominated in new and significant ways by mass media . Beckett was not consciously a disciple of McLuhan, but the cultural visibility of McLuhanism as a validation of television forms a bridge between intellectuals' pedagogical attitudes to experimental art-forms, and the paedocratic discourse in which television audiences are valued because of their childlike predilections rather than in spite of them.

Shades included linking sequences between the plays in which Martin Esslin and Melvyn Bragg discussed Beckett's drama over still images of three paintings by Henri Hayden, Munch's The Scream, Francis Bacon's Pope II 1951, and Giacometti's Woman for Venice VIII 1956. Beckett was positioned among twentieth-century European Modernists from the literary and theatre scene, and also from a broader arts culture including painting and sculpture, thus framing his work amid discourses about contemporaneity, formal experiment, and aesthetic and historic value. Beckett's work was given a pedagogic relation to its audience, seeking to provoke unconventional ways of seeing, hearing and experiencing represented space, bodies and time. Mise-en-scene, point of view, and relationships between image and sound or music in the plays were implicitly paralleled with formal devices from the visual, theatrical and plastic arts that assimilated them into television arts programme discourse. In the 1970s, scheduling practices disciplined the audience's relationship to Beckett's plays pedagogically, by screening them in arts programming slots, and shaped the expectations viewers brought to them. The first television version of Waiting for Godot (1961) began at the late evening time of 9.50pm, while Krapp's Last Tape (1963) began at 9.55pm. With a couple of exceptions, Beckett's television plays were all first shown on BBC2 once it started broadcasting, rather than the more widely watched $\mathrm{BBC1}$, and began in the late evening. Shades began at $9.00 \mathrm{pm}$, and Quad started at $10.40 \mathrm{pm}$. These were not programmes that would form the 
centrepiece of the schedule, and they often occupied timeslots that conflicted with BBC1's offering of a football match or an established drama series. As scheduling was increasingly refined as a tool for the attraction of maximal audiences, this paedocratic television culture pushed Beckett's work into an increasingly pedagogical margin.

Both Channel 4 and the Irish broadcaster RTE invested in the recent film versions of all Beckett's published plays, intended both for cinema exhibition and television screening (Frost and McMullan 2003). Channel 4's backing for 'Beckett on Film', is to some extent consistent with the channel's original remit, yet marks an interesting difference from the terms of its foundation in the early 1980s. Channel 4 was devised with a large and guaranteed income levied from the advertising revenues of Independent Television (ITV) companies, yet with an injunction from government not to pursue ITV's large audiences, and to be innovative, distinctively different from mainstream television, and to provide programmes for minorities. This was a largely pedagogic setup based on the post-war consensus that supported public service broadcasting throughout the 20th century, and it represented an enterprising yet troubled yoking together of commercial funding and the values of subsidised pedagogy. The contradictions in the cultural role of Channel 4 explain its seemingly hesitant and unplanned attitude to 'Beckett on Film'. It was intended in the early years of Channel 4 that its drama would refuse the comfortable forms of costume heritage drama and the adaptation of classics. Instead, contemporary, unfamiliar, immediate, innovative and consciously televisual work would be created. By 2001, however, Channel 4 was competing much more directly with $\mathrm{BBC} 2$ on a range of programmes designed for attractive niche audiences, in particular 18-25 year-olds. The ambitions of Channel 4 had become much more paedocratic, and much more conscious of audience value. This was directly reflected in the fate of 'Beckett on Film'.

The first British screenings of Beckett on Film in 2001 were on Channel 4 in an irregular collection of schedule positions either in the early or late evening. While the plays were sometimes given trailers before broadcast, in which they were presented as a special arts event, it was difficult for viewers to know more than a few days in advance when they would be shown, and they bore no obvious relation to the channel's normal scheduling policy. They were not part of a regular series of drama programming, or connected to arts magazine programmes (like BBC's Arena or Lively Arts series) or dramas by other writers. Individual plays were broadcast singly, with whole longer plays and shorter plays in different slots of unequal length rather than as a package occupying a consistent period of broadcast time. The uncertain relationship between the plays and the rest of the channel's output, and the unconventional pattern of scheduling, must have contributed to the season's low ratings and confusion about which viewers the plays were aimed at. This first showing of the Beckett on Film season displays some of the pedagogic relations with the audience that I have discussed above, in their trailing and promotion, and harks back to some extent to British broadcasters' policy to mix programmes together in the schedule so that audiences might come across them by chance and be stimulated by relatively demanding fare that they might not 
consciously choose to view. This kind of scheduling is now rare in British television and belongs to a pre-1980 conception of public service broadcasting in which the audience is conceived as a citizenry whose cultural knowledge and involvement could be gently raised by insinuating 'quality' material amongst popular entertainment and other paedocratic forms.

However, the second period in which the Beckett on Film adaptations were shown was quite different in character. By 2004, the plays were being scheduled as if they were educational broadcasts for schools, thus adopting an explicit pedagogic address to the audience. In the week of Saturday 28 February - Friday 4 March 2004, for example, Channel 4 showed the Beckett on Film productions in their schools programme slot in the middle of weekday mornings. The plays were repositioned as educational programmes for the secondary school audience who may be studying the plays in the English or Drama syllabus. Listings magazines such as the Radio Times grouped all of the day's Channel 4 programmes for schools together in one block of text giving information such as programme titles and starting times, but also noting the age group for which each programme was intended (as an aid to teachers or parents). For instance, on Thursday 4 March, the 4Learning educational slot from 9.30-12.00 included four plays from the Beckett on Film season. They were preceded at 10.40 by the programme for English literature students aged 7-11, What's So Good About J.K. Rowling, discussing the well-known author of the Harry Potter novels. At 10.55 What Where appeared, targeted at a suggested 14-19 year-old age-group. These are secondary school students who may be taking GCSE examinations (at age 16) or the final school examinations that can prepare them for Further or Higher Education. Following What Where came Footfalls, Come and Go, and Act without Words 2, with the same suggested age of audience, then educational programmes finished. Clearly, the plays were not being offered to a general audience, but were a contribution to British television's statutory support for the school curriculum, as resources for study and as part of television's pedagogic function in its most explicit and functional form.

\section{Conclusion: Despite the Audience}

The uneven but consistent shift towards framing Beckett's television plays and television adaptations of his theatre work pedagogically is the result of the rise of paedocracy in British television culture. The ways that audiences choose the programmes they view, and the reactions they have to programmes, have gained increasing significance for broadcasters as television has become an industry rather than a service. My work on the records detailing audience reception of Beckett's television plays (Bignell 2003) has shown that their small audiences often thought they were inaccessible and boring. But the most striking fact about the audience research information is its lack of bearing on the continuing commissioning and production of Beckett's television plays from the mid-1960s to the early 1980s, and the commissioning of the Beckett on Film series at the beginning of the twenty-first century. Clearly, the pedagogic discourse was sufficiently powerful in 
the production culture and the executive policy-making echelons of the BBC and Channel 4 for Beckett's work to continue to be a legitimate focus of special interest, effort and financial investment. The distinction between 'mature' and 'childish' audiences was always imaginary: it was and is a matter of discursive construction that enables a politics of media communication. Despite its questionable theoretical basis, the pedagogic discourse permits the legitimation of formal experiment, the valuation of authorship, and the self-validation of producers and production practices within television institutions. In this article I have aimed neither to definitively value or devalue Beckett's television plays as cultural interventions or as texts, but instead to consider some of the conditions for their evaluation. It is part of the proper role of criticism to delineate the parameters of the others in whose name communication is undertaken, with an awareness of those others' necessary indeterminacy, recognizing and critiquing the continual attempts to grasp and discipline the other. For the audience as indeterminate other functions as the receding horizon that both borders and facilitates the possibilities of textuality, and thus the possible meanings and significance of Beckett's work in relation to the changing conceptions of audience negotiated in television and writing about television.

\section{Acknowledgements}

I gratefully acknowledge a grant from The Leverhulme Trust that enabled me to pursue research on $\mathrm{BBC}$ versions of Beckett's plays, and a British Academy travel grant to present the paper on which the article is based at the 'After Beckett/D'après Beckett' conference in Sydney, 2003. I am grateful to the BBC Written Archives Centre in Reading, Great Britain, for providing access to documents relating to $\mathrm{BBC}$ productions of Beckett's plays. 


\section{Works Cited}

Ben-Zvi, Linda, “Samuel Beckett’s Media Plays”, in Modern Drama 28:1 (1985), 22-37.

Bignell, Jonathan, "Beckett in Television Studies”, in Journal of Beckett Studies 10: 1-2 (2001-2), $105-18$.

--, "Writing the Child in Media Theory", in Yearbook of English Studies 32 (2002), 127-39.

--, "Beckett at the BBC: The Production and Reception of Samuel Beckett's Plays for Television", in Drawing on Beckett: Portraits, Performances and Cultural Contexts, ed. Linda BenZvi (Tel Aviv: Assaph, 2003), 165-82.

Buckingham, David, Moving Images: Understanding Children's Emotional Responses to Television (Manchester: Manchester UP, 1996).

Frost, Everett and Anna McMullan, "The Blue Angel Beckett on Film Project: Questions of Adaptation, Aesthetics, and Audience in Filming Samuel Beckett's Theatrical Canon", in Drawing on Beckett: Portraits, Performances and Cultural Contexts, ed. Linda Ben-Zvi (Tel Aviv: Assaph, 2003), 215-38.

Gombrich, Ernst, Art and Illusion (London \& New York: Phaidon, 1960).

Hartley, John, Tele-ology: Studies in Television (London: Routledge, 1992).

Hodge, Bernard and David Tripp, Children and Television: A Semiotic Approach (Cambridge: Polity, 1986).

Kalb, Jonathan, "The Mediated Qixote: The Radio and Television Plays, and 'Film'”, in The Cambridge Companion to Beckett, ed. John Pilling (Cambridge: Cambridge UP, 1994), pp.124-44.

McLuhan, Marshall, Understanding Media: The Extensions of Man (London: Ark, 1987).

Singleton-Turner, Roger, Television and Children (London: BBC, 1994).

Voigts-Virchow, Eckart (1998), "Exhausted Cameras - Beckett in the TV-Zoo", in Saтиel Beckett: A Casebook, ed. Jennifer Jeffers (New York and London: Garland, 1998), 22549.

Walker, John A., Arts TV: A History of Arts Television in Britain (London: John Libbey, 1993). 